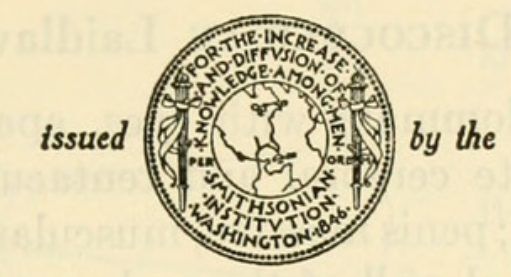

SMITHSONIAN INSTITUTION

U. S. NATIONAL MUSEUM

\title{
SOME POLYCLAD FLATWORMS FROM POLYNESIA AND MICRONESIA
}

\section{By Libbie H. Hyman}

The Indo-Pacific area is commonly stated to be the richest in marine littoral invertebrates of any place on the globe and no doubt the Turbellaria share in this exuberance, but little has been done on Indo-Pacific members of this group except in the order Polycladida and even this group has been collected only sporadically. Most of the descriptions of Indo-Pacific polyclads are old and inadequate, so subsequent recognition is difficult if not impossible unless the original specimens can be recovered, and some collections from the area, as those of the Siboga and of Semper in the Philippines (mentioned by Stummer-Traunfels, 1933), have never been described in print, although Stummer-Traunfels published colored figures of some of the species.

The present study concerns a small collection of polyclads from tropical islands of the central and western Pacific sent for determination by the U. S. National Museum. As I have recently published a glossary of terms and full definitions of subordinal, familial, and generic categories (Hyman, 1953), it appears unnecessary to repeat these definitions here. Definitions will be given only for categories not appearing in that publication. 


\section{Order POLYCLADIDA}

\section{Suborder ACOTYLEA}

\section{Section Craspedommata}

\section{Family Discocelidae Laidlaw, 1903}

Definition: Craspedommata with eyes, apart from the marginal band, limited to definite cerebral and tentacular clusters; tentacles wanting or rudimentary; penis massive, muscular, lobulated, depending vertically from the dorsal wall of the male antrum; penis edged with numerous small prostatic apparatuses, which may also be present in the antral wall; Lang's vesicle present, usually crescentic.

\section{Genus Discocelis Ehrenberg, 1832}

Thalamoplana Laidlaw, 1904, p. 132.

Definition: Discocelidae without prostatic vesicle or antral pockets occupied by a large prostatoid.

Type species: Planaria lichenoides Mertens, 1832.

Discocelis insularis, new species

Figures $1, a, b ; 2, a, c$

Material: Two specimens of this species were taken by J. P. E. Morrison at night, Sept. 2, 1952, in Raroia Atoll, Tuamotu Islands.

Explanation OF Figures

1, marginal eyes

2 , cerebral eye cluster

3 , tentacular eye cluster

4, uteri

5, pharynx

6 , male apparatus

7 , male gonopore

8, Lang's vesicle

9 , sperm ducts

10 , seminal vesicle

11, ejaculatory duct

12 , male antrum

13 , penis

14 , prostatic apparatuses

15 , muscular pocket

16 , female gonopore

17 , vagina

18 , cement glands

19 , entrance of oviduct into vagina

20, duct of Lang's vesicle

21, anterior horn of Lang's vesicle
22 , cerebro frontal eyes

23 , brain

24 , mouth

25 , prostatic vesicle

26, prostatic duct

27 , spermiducal bulbs

28 , penis sheath

29 , penis papilla

30 , vaginal duct

31 , vaginal pore

32 , tentacles

33 , tubercles

34 , common sperm duct

35 , female antrum

36 , accessory prostatic vesicles

37 , cirrus sac

38 , teeth in cirrus sac

39 , copulatory bursa

40 , spermiducal vesicle inside bursa

41 , sucker 

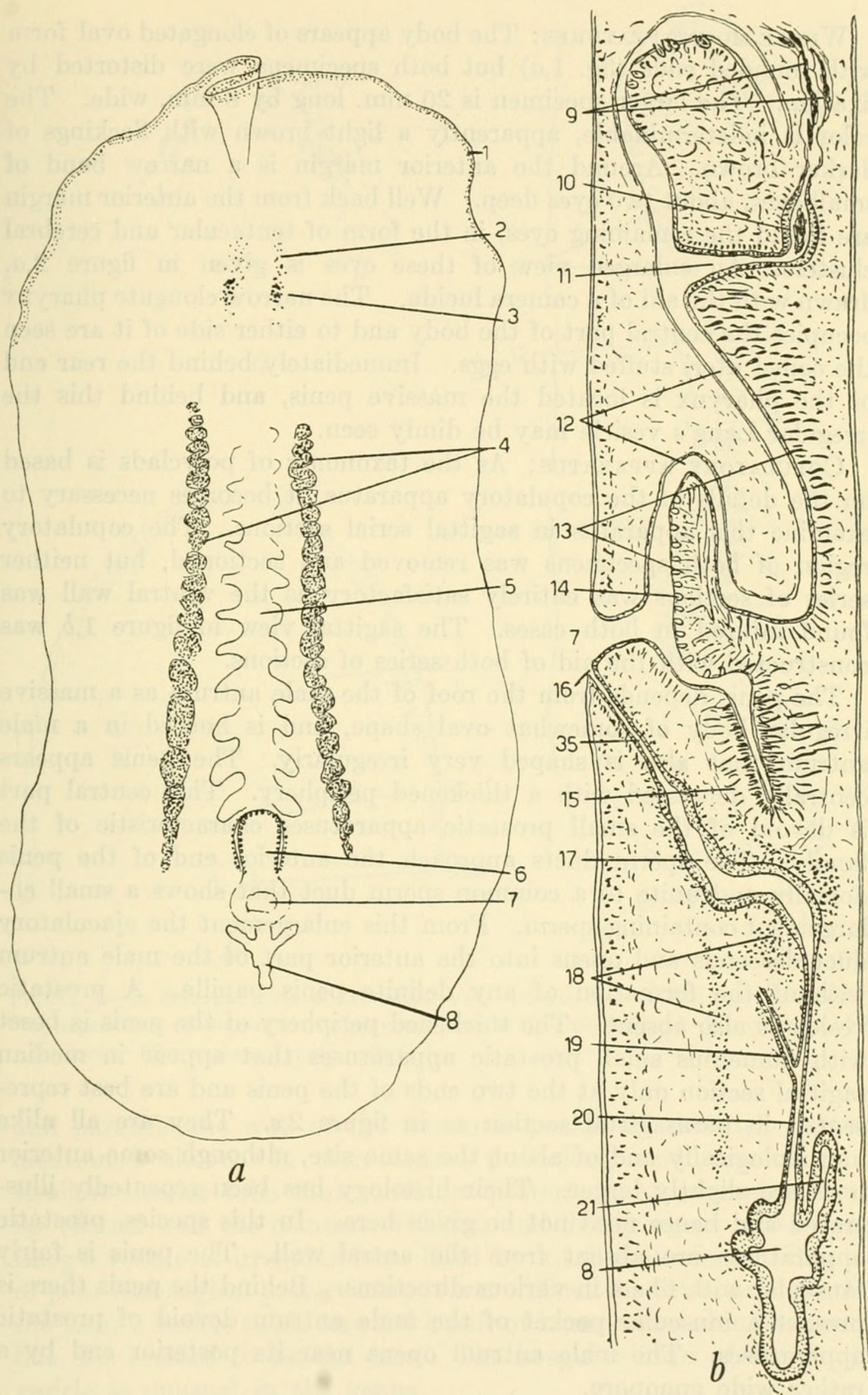

Figure 1.-Discocelis insularis: $a$, entire worm as cleared whole mount; $b$, sagittal view of copulatory apparatuses. (For explanation see facing page.) 
Whole mount Features: The body appears of elongated oval form with rounded ends (fig. 1,a) but both specimens were distorted by fixation. The larger specimen is $20 \mathrm{~mm}$. long by $8 \mathrm{~mm}$. wide. The color is indeterminable, apparently a light brown with fleckings of darker brown. Around the anterior margin is a narrow band of small eyes, about two eyes deep. Well back from the anterior margin are found the remaining eyes, in the form of tentacular and cerebral clusters. An enlarged view of these eyes is given in figure 2,a, drawn with the aid of a camera lucida. The narrow elongate pharynx occupies the central part of the body and to either side of it are seen the coiled uteri stuffed with eggs. Immediately behind the rear end of the pharynx is located the massive penis, and behind this the irregular Lang's vesicle may be dimly seen.

Copulatory apparatus: As the taxonomy of polyclads is based on the details of the copulatory apparatus, it becomes necessary to examine this apparatus in sagittal serial sections. The copulatory region of both specimens was removed and sectioned, but neither series of sections was entirely satisfactory as the ventral wall was found injured in both cases. The sagittal view in figure $1, b$ was constructed with the aid of both series of sections.

The penis depends from the roof of the male antrum as a massive irregular body of somewhat oval shape, and is housed in a male antrum that also is shaped very irregularly. The penis appears centrally depressed with a thickened periphery. This central part is devoid of the small prostatic apparatuses characteristic of the family. The sperm ducts approach the anterior end of the penis dorsally and unite to a common sperm duct that shows a small enlargement containing sperm. From this enlargement the ejaculatory duct descends and opens into the anterior part of the male antrum without the formation of any definite penis papilla. A prostatic vesicle is also absent. The thickened periphery of the penis is beset with numerous small prostatic apparatuses that appear in median sagittal section only at the two ends of the penis and are best represented in parasagittal section as in figure 2,c. They are all alike morphologically and of about the same size, although some anterior ones are slightly larger. Their histology has been repeatedly illustrated and hence need not be given here. In this species, prostatic apparatuses are absent from the antral wall. The penis is fairly muscular with fibers in various directions. Behind the penis there is present a muscular pocket of the male antrum devoid of prostatic apparatuses. The male antrum opens near its posterior end by a rather wide gonopore.

Shortly behind the male gonopore, the female gonopore opens narrowly. From it the vagina ascends with a decided posterior slant 

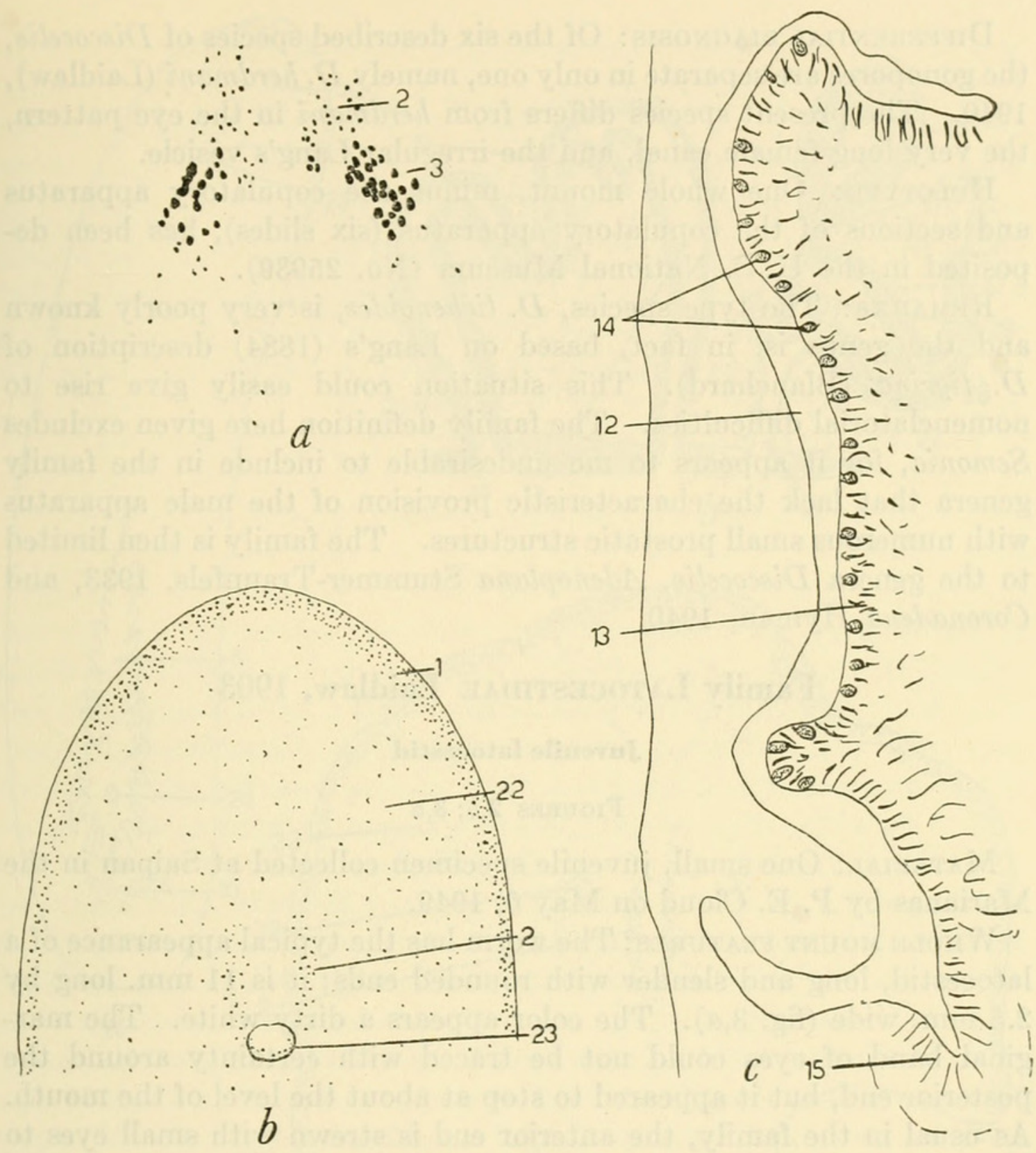

Figure 2.- $a$, Enlarged view of tentacular and cerebral eyes of Discocelis insularis; $b$, enlarged view of anterior end of juvenile latocestid; $c$, parasagittal view of penis of $D$. insularis. (For explanation see page 66.)

and parallels the wall of the muscular pocket of the male antrum mentioned above. It then arches posteriorly and narrows to a straight slender tube that continues posteriorly after receiving into its ventral wall the common oviduct, and finally opens into a large Lang's vesicle of irregular form lined by a tall epithelium. Because of poor histological preservation it was difficult to determine whether the Lang's vesicle sends forward a pair of horns as usual in the genus, but this seemed to be the case. The irregular form of the Lang's vesicle is unusual in the genus. 
Differential diagnosis: Of the six described species of Discocelis, the gonopores are separate in only one, namely $D$. herdmani (Laidlaw), 1940. The present species differs from herdmani in the eye pattern, the very long female canal, and the irregular Lang's vesicle.

Holotype: One whole mount, minus the copulatory apparatus and sections of the copulatory apparatus (six slides), has been deposited in the U. S. National Museum (No. 25939).

Remarks: The type species, $D$. lichenoides, is very poorly known and the genus is, in fact, based on Lang's (1884) description of D. tigrina (Blanchard). This situation could easily give rise to nomenclatorial difficulties. The family definition here given excludes Semonia, for it appears to me undesirable to include in the family genera that lack the characteristic provision of the male apparatus with numerous small prostatic structures. The family is then limited to the genera Discocelis, Adenoplana Stummer-Traunfels, 1933, and Coronadena Hyman, 1940.

\section{Family Latocestidae Laidlaw, 1903}

\section{Juvenile latocestid}

Figures $2, b ; 3, a$

Material: One small, juvenile specimen collected at Saipan in the Marianas by P. E. Cloud on May 6, 1949.

WhOLE MOUNT FEATURES: The worm has the typical appearance of a latocestid, long and slender with rounded ends; it is $11 \mathrm{~mm}$. long by $2.5 \mathrm{~mm}$. wide (fig. 3,a). The color appears a dirty white. The marginal band of eyes could not be traced with certainty around the posterior end, but it appeared to stop at about the level of the mouth. As usual in the family, the anterior end is strewn with small eyes to the level of the brain (fig. 2,b). Directly in front of the brain they are aggregated into two linear cerebral clusters. The pharynx is in the posterior body half and broadens posteriorly where it terminates in a rounded part bearing the mouth.

Copulatory apparatus: As usual in the family, the copulatory apparatus is located in the short posterior region between the posterior end of the pharyngeal cavity and the posterior body margin. The female pore was detectable here in the whole mount, but sections of this postpharyngeal region revealed only traces of the copulatory apparatus. The specimen is thus immature and cannot be placed generically, although it is highly probable that it belongs to Latocestus. The eye pattern appears different from that of described species of Latocestus.

The specimen mounted whole plus the sections of the postpharyngeal region has been returned to the U. S. National Museum (No. 25940). 


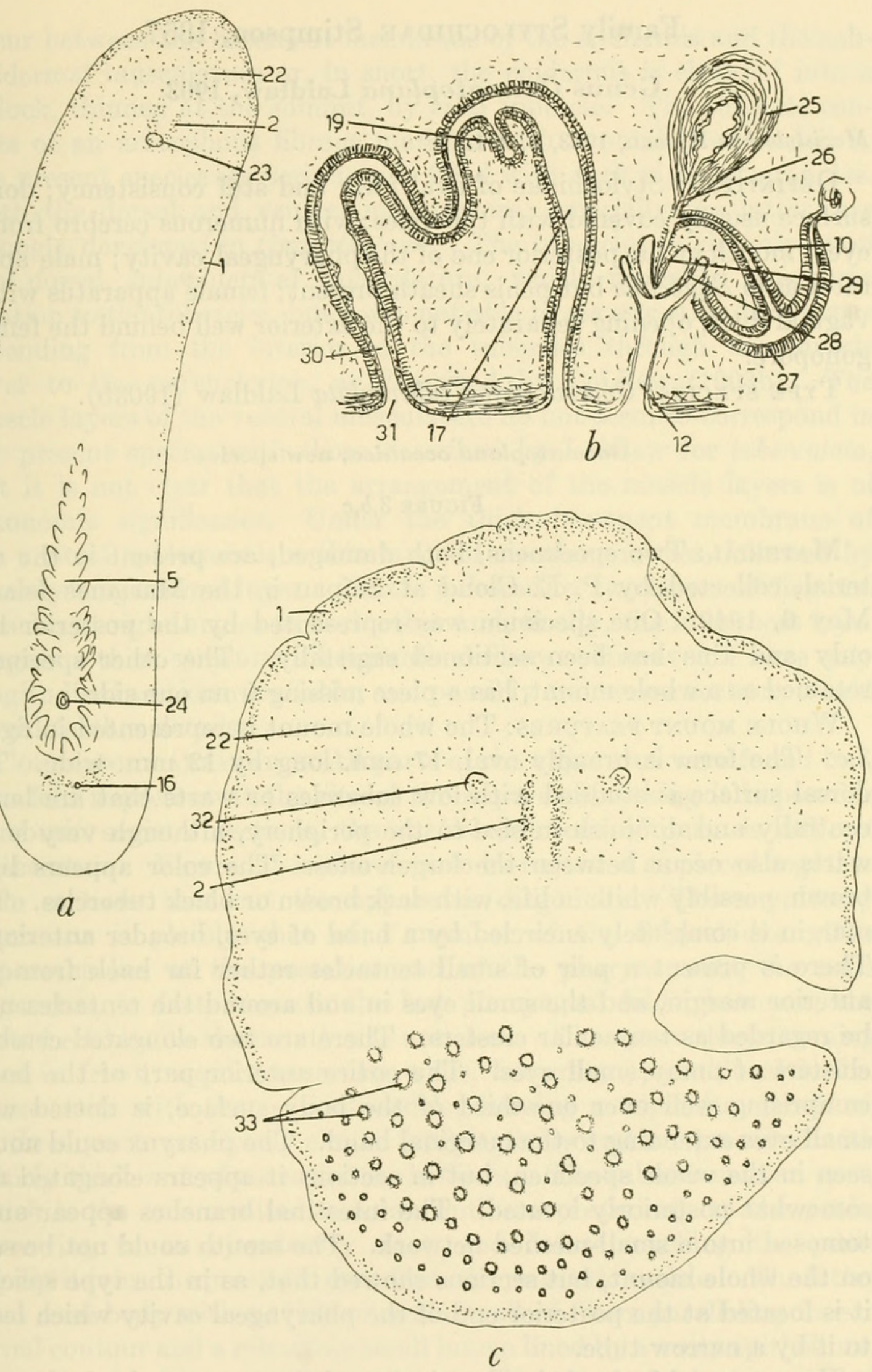

Figure 3.- $a$, Juvenile latocestid, view of entire cleared worm; $b$, Ommatoplana oceanica, sagittal view of copulatory apparatuses; $c$, same, view of cleared holotype. (For explanation see page 66.) 


\section{Family Stylochidae Stimpson, 1857 \\ Genus Ommatoplana Laidlaw, 1903}

Mexistylochus Hyman, 1953, p. 291.

Definition: Stylochidae of oval form and stiff consistency; dorsal surface usually covered with tubercles; with numerous cerebro frontal eyes; mouth at the posterior end of the pharyngeal cavity; male apparatus as in Stylochus but penis sheath present; female apparatus with a vaginal duct, opening separately to the exterior well behind the female gonopore.

Type SPECIES: Ommatoplana tuberculata Laidlaw (1903b).

\section{Ommatoplana oceanica, new species}

Figure $3, b, c$

Material: Two specimens, both damaged, are present in the material, collected by P. E. Cloud at Saipan in the Marianas Islands May 6, 1949. One specimen was represented by the posterior half only and this has been sectioned sagittally. The other specimen, retained as a whole mount, has a piece missing from one side.

Whole mount FEATuRes: The whole mount is represented in figure $3, c$. The form is broadly oval, $17 \mathrm{~mm}$. long by $12 \mathrm{~mm}$. wide. The dorsal surface is studded with low tubercles or warts that are larger centrally and diminish in size to the periphery, although very small warts also occur between the larger ones. The color appears light brown, possibly white in life, with dark brown or black tubercles. The margin is completely encircled by a band of eyes, broader anteriorly. There is present a pair of small tentacles rather far back from the anterior margin, and the small eyes in and around the tentacles may be regarded as tentacular clusters. There are two elongated cerebral clusters of many small eyes. The entire anterior part of the body, comprising well over one-third of the body surface, is dotted with small eyes extending to the marginal band. The pharynx could not be seen in the whole specimen, but in sections it appears elongated and somewhat posteriorly located. The intestinal branches appear anastomosed into a small-meshed network. The mouth could not be seen on the whole mount, but sections showed that, as in the type species, it is located at the posterior end of the pharyngeal cavity which leads to it by a narrow tube.

Histology: Much of the description of the type species is devoted to the general histology and a good figure is given of the general appearance of a section. As shown in this figure, the dorsal tubercles 
occur between the basement membrane of the epidermis and the subepidermal musculature or, in short, the epidermis is elevated into a hillock, thinned at the summit, by each tubercle. The tubercle consists of an amorphous fibrous material with a number of nuclei; in the present species its periphery is filled with dark pigment granules. Both the dorsal and ventral musculature, especially the latter, are strongly developed in Ommatoplana. The tubercles lie directly upon the dorsal subepidermal musculature, which probably has some relation to the tubercles, but I was not able to see any strands of tissue extending from the interior of the tubercles through the muscle layer to the parenchyma, as described by Laidlaw (1903b). The muscle layers of the ventral musculature do not seem to correspond in the present species with those described by Laidlaw for tuberculata, but it is not clear that the arrangement of the muscle layers is of taxonomic significance. Under the thick basement membrane of the ventral epidermis is a thin layer of circular muscles, followed by a heavy longitudinal layer. This is followed by two layers of diagonal muscles at right angles to each other and, finally, the innermost layer is again a thick stratum of longitudinal fibers. However, I have only longitudinal sections available, and possibly transverse sections would reveal further details.

Copulatory apparatus: All parts of the apparatus were found but, as a fold is present at the site of the apparatus making it impossible to obtain sagittal sections, the spatial relations of parts is difficult to ascertain. Figure $3, b$ is therefore to be regarded as pieced together from sections that cut the apparatus diagonally. The copulatory apparatus is plainly that of a member of the Stylochidae. The apparatus lies at the posterior end of the pharynx with the male apparatus, in fact, beneath the last pharyngeal folds; however, the spatial relation to the mouth was not clear. The sperm ducts, coming from in front, acquire muscular walls, becoming spermiducal bulbs. These unite with the seminal vesicle, forming a tripartite structure; all three parts are closely similar histologically and are provided with a fairly thick wall of circular muscle fibers. The tubular median part, which is the true seminal vesicle, continues posteriorly to the penis, narrowing to an ejaculatory duct, and before reaching the penis papilla it joins the prostatic duct from the prostatic vesicle. The latter is an oval body with a thick muscular wall of fibers paralleling its external contour and a relatively small lumen lined by a wavy epithelium. Prostatic glands are not in evidence. The prostatic duct, encircled by circular muscle fibers, joins the ejaculatory duct and the common duct extends through the penis papilla to its tip. The penis papilla 
is small, somewhat slender, and is housed in a part of the male antrum (penis pocket) separated from the general male antrum by a penis sheath, a circular fold with rather thin margins projecting into the male antrum. Distal to the penis sheath the male antrum proceeds as a somewhat elongated tube to the male gonopore.

The female gonopore occurs not far behind the male pore and leads into a tubular vagina invested with a layer of circular fibers. The vagina proceeds dorsally, widening considerably, then curves backward, receiving the common oviduct at the curve. It then continues posteriorly and downwards as a vaginal duct. This duct makes a loop and proceeds, widening somewhat, to the vaginal pore in the midventral wall, somewhat farther behind the female gonopore than the latter is from the male gonopore. The vaginal duct is heavily muscularized with circular fibers.

Differntial diagnosis: Ommatoplana oceanica differs from other known species of the genus in the presence of tentacles and in the black color of the tubercles.

Holotype: One whole mount deposited in the U. S. National Museum (No. 25941); also, one set of sagittal sections of the copulatory region.

REMARKs: If I am correct in assigning this species to Ommatoplana, then Ommatoplana is a stylochid, not a cryptocelid as supposed by Bock (1913). Certainly, because of the loss of important sections, the original description of Ommatoplana does not furnish the necessary information to decide to what family of the Craspedommata it belongs. It is further evident that Mexistylochus Hyman, 1953, is a synonym of Ommatoplana. As the combination Ommatoplana tuberculata already exists, it becomes necessary to suggest a new specific name for my species Mexistylochus tuberculatus, and I propose mexicana. The genus Ommatoplana then comprises at present the species tuberculata Laidlaw, 1903, mexicana, new name, levis (Hyman, 1953 ) and the present oceanica. The last three species are very similar as to eye arrangement but, according to Laidlaw's figure, tuberculata differs decidedly in this respect. The peculiar disposition of the cerebro frontal eyes in this figure, without bilateral arrangement or cerebral or tentacular clusters, suggests some abnormality or injury in the specimen in question. O. levis differs from the other three species in lacking the characteristic dorsal tubercles. The great similarity of the copulatory apparatus in the three species in which it is fully known is very surprising. Anastomosis of the intestinal branches into a fine-meshed network appears characteristic of the genus. Ommatoplana is very close to Cryptophallus but differs from it in the well developed, though small, prostatic vesicle and in the separate opening of the vaginal duct. 

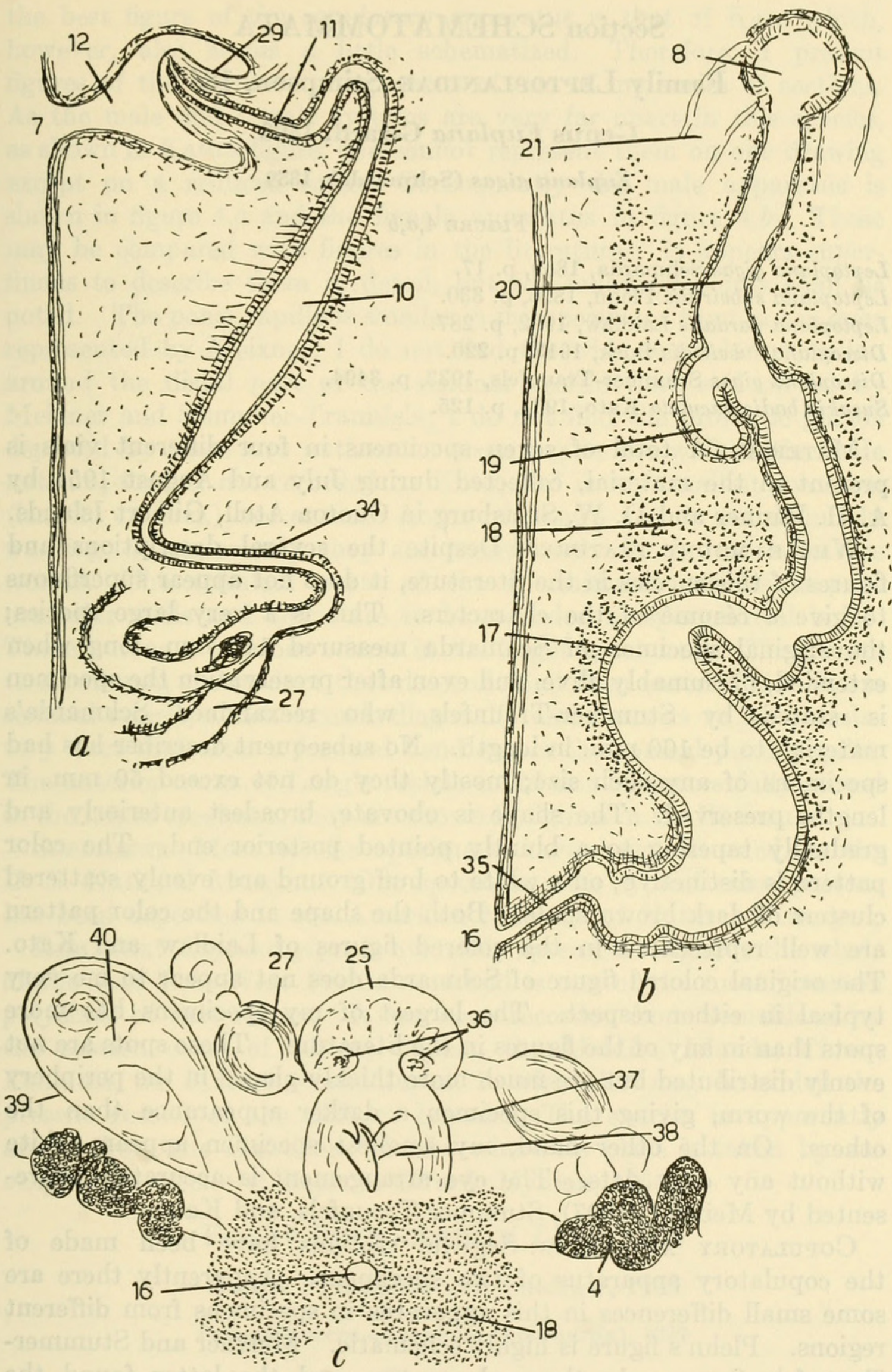

Figure 4.-Euplana gigas, sagittal view of male copulatory apparatus; $b$, same, of female copulatory apparatus; $c$, copulatory apparatus of Paraplanocera oligoglena, as seen from above in cleared specimen, ventral view, showing teeth in the cirrus sac. (For explanation see page 66.) 


\section{Section SCHEMATOMMATA}

\section{Family Leptoplanidae Stimpson, 1857}

\section{Genus Euplana Girard, 1893}

Euplana gigas (Schmarda), 1859

Figure $4, a, b$

Leptoplana gigas Schmarda, 1859, p. 17.

Leptoplana subviridis Plehn, 1896, p. 330.

Leptoplana pardalis Laidlaw, 1902, p. 287.

Discoplana subviridis Bock, 1913, p. 220.

Discoplana gigas Stummer-Traunfels, 1933, p. 3494.

Susakia badiomaculata Kato, 1934, p. 125.

Material: A total of seven specimens in four different vials is present in the material, collected during July and August 1951 by A. H. Banner and D. W. Strasburg in Onotoa Atoll, Gilbert Islands.

Whole mount features: Despite the several descriptions and figures of this species in the literature, it does not appear superfluous to give a résumé of the characters. This is a very large species; the original specimen of Schmarda measured $140 \mathrm{~mm}$. long when extended, presumably alive, and even after preservation the specimen is stated by Stummer-Traunfels, who reexamined Schmarda's material, to be $100 \mathrm{~mm}$. in length. No subsequent describer has had specimens of any such size; mostly they do not exceed $50 \mathrm{~mm}$. in length, preserved. The shape is obovate, broadest anteriorly and gradually tapering to a bluntly pointed posterior end. The color pattern is distinctive; on a white to buff ground are evenly scattered clusters of dark brown spots. Both the shape and the color pattern are well represented in the colored figures of Laidlaw and Kato. The original colored figure of Schmarda does not appear to me very typical in either respect. The largest of my specimens has more spots than in any of the figures in the literature. These spots are not evenly distributed but are much more thickly placed in the periphery of the worm, giving this specimen a darker appearance than the others. On the other hand, my smallest specimen appears white without any dark dots. The eye arrangement is accurately represented by Meixner (1907), Stummer-Traunfels, and Kato.

Copulatory apparatus: Sagittal sections have been made of the copulatory apparatus of two specimens. Apparently there are some small differences in this apparatus in specimens from different regions. Plehn's figure is highly schematic. Meixner and StummerTraunfels figure only the male system and the latter found the female system damaged in the Schmarda specimen. Consequently, 
the best figure of the copulatory apparatus is that of Kato which, however, also seems a little schematized. Therefore, I present figures of the copulatory apparatus of one of my series of sections. As the male and female systems are very far apart in this species, as shown in Kato's figure, one cannot represent them on one drawing except on a reduced scale. Consequently the male apparatus is shown in figure $4, a$ and the female apparatus in figure $4, b$. These may be compared with figures in the literature. It appears superfluous to describe them in detail, but the following points shall be noted. The penis papilla is smaller in my specimens than in the ones represented by Meixner; I do not find the wide muscular provision around the distal part of the seminal vesicle that is depicted by Meixner and Stummer-Traunfels; I do not find the prostatic glands depicted by these two authors as occurring in the wall of the male antrum, further not recorded by Kato; and in my smallest specimen (length, $16 \mathrm{~mm}$.) the anterior horns of Lang's vesicle are definitely wanting, so apparently they are present only in the more mature worms. The terminal parts of the spermiducal vesicles acquire muscular walls and hence are to be regarded as spermiducal bulbs. These pursue a tortuous course in the larger specimens. They unite to a common sperm duct that descends and then enters the fusiform seminal vesicle, which ascends diagonally and narrows to an ejaculatory duct that after a forward bend enters the conical penis papilla. The anterior horns of Lang's vesicle could not be successfully traced in the larger specimen; they are shown in figures in the literature.

Specimens: Most of the specimens have been returned to the U. S. National Museum. One specimen with typical color pattern has been deposited in the American Museum of Natural History.

Remarks: Euplana gigas is evidently spread throughout the whole of the vast Indo-West Pacific area and is one of the most common polyclads of that region. It has been recorded from Somaliland on the eastern coast of Africa, Ceylon, the Maldive Islands, Timor, Funafuti, the Moluccas, and Japan, to which list may be added the present record of the Gilbert Islands. The species is apparently absent from the Hawaiian Islands, where its place is taken by another large species of Euplana Girard (Hyman, 1954).

\section{Family Planoceridae Lang, 1884 \\ Genus Paraplanocera Laidlaw, 1903 \\ Paraplanocera oligoglena (Schmarda), 1859}

Figure 4,c

Stylochus oligoglenus Schmarda, 1859, p. 34.

Stylochus amphibolus Schmarda, 1859, p. 34. 
Planocera olygoglena Lang, 1884, p. 444.

Planocera amphibola Lang, 1884, p. 444.

Planocera discus, Willey, 1897, p. 155.

Paraplanocera laidlawi Jacubowa, 1906, p. 115.

Paraplanocera discus Bock, 1913, p. 246.

Paraplanocera oligoglena Stummer-Traunfels, 1933, p. 3487.

Material: One specimen collected by S. F. MacNeil on a reef flat, Kwajalein Atoll, South Loi Island, Marshall Islands, no date.

Whole mount features: The specimen is broadly oval, $18 \mathrm{~mm}$. long and $16 \mathrm{~mm}$. wide. The copulatory apparatus as seen in the whole mount is shown in figure 4,c. This agrees with the copulatory apparatus of $P$. oligoglena except that in addition to the two large teeth in the cirrus sac characteristic of this species there are two additional smaller teeth. Puzzling coils were further seen in the copulatory bursa. It was therefore thought necessary to section the copulatory apparatus. This showed complete agreement with oligoglena in all details, apart from the extra teeth in the cirrus sac; the coils in the bursa were found to be those of the right spermiducal vesicle that had somehow got pushed into the bursa. As I have recently described this species in great detail (Hyman, 1953), further description here appears superfluous.

Specimen: The specimen as whole mount minus the copulatory apparatus and serial sections of the copulatory apparatus (seven slides) have been returned to the U. S. National Museum.

Remarks: Paraplanocera oligoglena is cosmopolitan in IndoPacific tropical and subtropical waters. It has been recorded from Ceylon, New Britain, New Caledonia, Gulf of California, Hawaii (Hyman, 1954), and now from the Marshall Islands. Records from several other places in the Indian and Pacific Oceans are given by Prudhoe (1945), but some uncertainty exists as to the specific identification and the number of valid species of the genus. No species of the genus has been taken in the Atlantic Ocean.

\section{Suborder COTYLEA}

Family Pseudoceridae Lang, 1884

\section{Genus Pseudoceros Lang, 1884}

\section{Pseudoceros micronesianus, new species}

Figure 5

Material: This species is represented by two specimens-a larger one taken by P. E. Cloud in a lagoon near Managaha Island, west of Saipan, June 20, 1949, and a smaller one collected by A. H. Banner, at Onotoa Atoll, Gilbert Islands, July 29, 1951. 


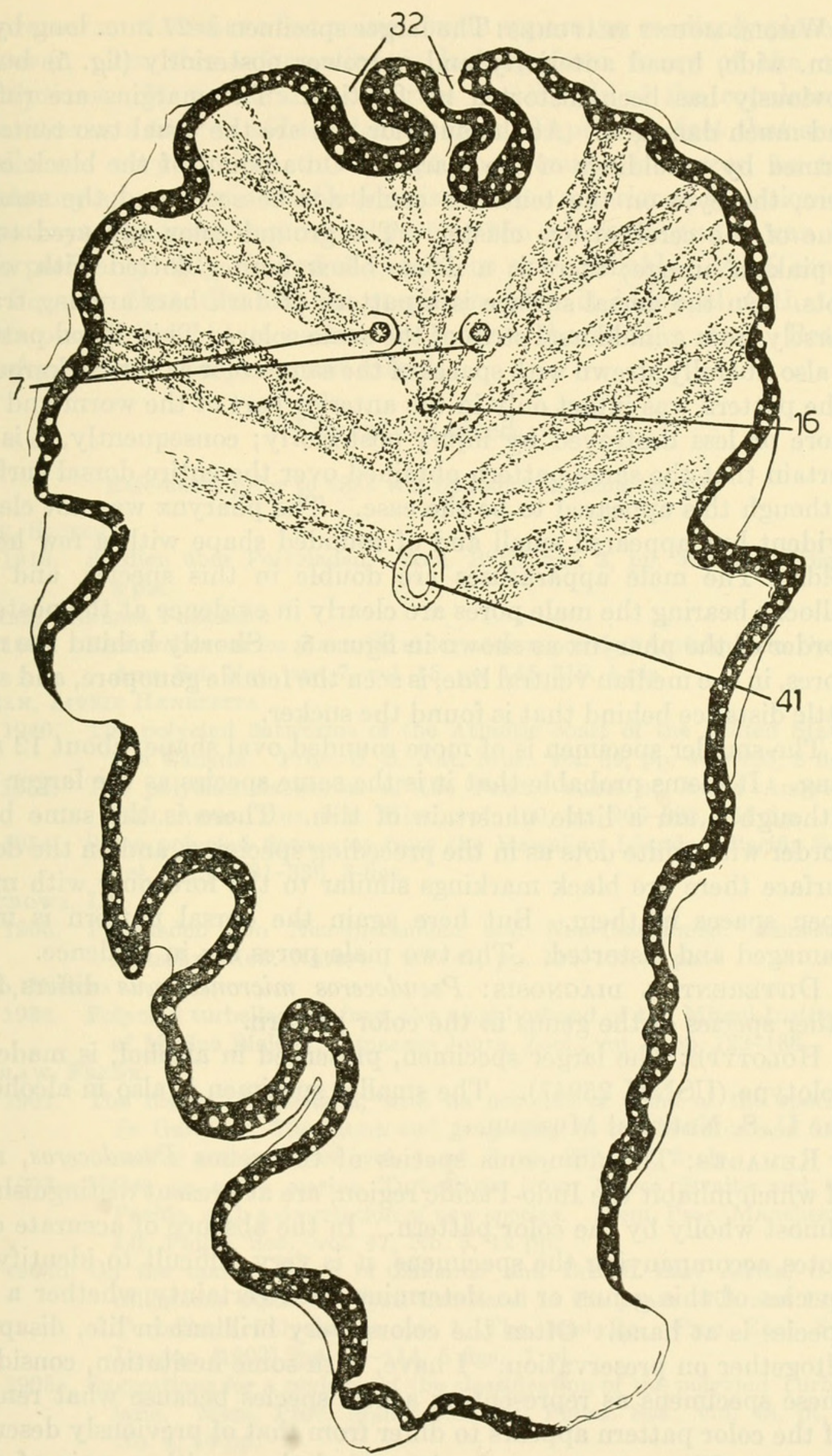

Figure 5.-Pseudoceros micronesianus, view of holotype in alcohol. (For explanation see page 66.) 
Whole Mount Features: The larger specimen is $27 \mathrm{~mm}$. long by 16 $\mathrm{mm}$. wide, broad anteriorly and narrower posteriorly (fig. 5) but it obviously has been distorted by fixation. The margins are ruffled and much damaged. At the anterior end are the usual two tentacles formed by upfoldings of the margin. On account of the black color here, the eyes on the tentacles could not be seen, and the same is true of the cerebral eye cluster. The ground color appeared to be a pinkish orange; there is a dense black border dotted with white dots. On the dorsal surface is a pattern of dark bars arching transversely from a middorsal strip of the same color. This dorsal pattern is also liberally strewn with spaces of the same color as the background. The pattern was intact only in the anterior part of the worm and was more or less destroyed by injury posteriorly; consequently, it is not certain that the same pattern obtained over the entire dorsal surface, although this appeared to be the case. The pharynx was not clearly evident but appeared small and of rounded shape with a few heavy folds. The male apparatuses are double in this species, and two hillocks bearing the male pores are clearly in evidence at the posterior border of the pharynx as shown in figure 5. Shortly behind the male pores, in the median ventral line, is seen the female gonopore, and some little distance behind that is found the sucker.

The smaller specimen is of more rounded oval shape, about $12 \mathrm{~mm}$. long. It seems probable that it is the same species as the larger one, although I am a little uncertain of this. There is the same black border with white dots as in the preceding specimen, and on the dorsal surface there are black markings similar to the foregoing with many open spaces in them. But here again the dorsal pattern is much damaged and distorted. The two male pores are in evidence.

Differential diagnosis: Pseudoceros micronesianus differs from other species of the genus in the color pattern.

HоLотүPE: The larger specimen, preserved in alcohol, is made the holotype (USNM 25947). The smaller specimen is also in alcohol in the U. S. National Museum.

(-Remarks: The numerous species of the genus Pseudoceros, most of which inhabit the Indo-Pacific region, are at present distinguishable almost wholly by the color pattern. In the absence of accurate color notes accompanying the specimens, it is very difficult to identify the species of this genus or to determine with certainty whether a new species is at hand. Often the colors, very brilliant in life, disappear altogether on preservation. I have, with some hesitation, considered these specimens as representing a new species because what remains of the color pattern appears to differ from that of previously described species. The present species is one of those with a pair of male 
apparatuses; others have but a single male apparatus, medianly placed. However, even this information is lacking from many of the old descriptions. It is desirable to figure the details of the copulatory apparatus as a further aid to identification, despite the fact that such details are very similar throughout the genus. However, as the copulatory apparatus in the Cotylea is near the anterior end, sectioning it destroys the most important part of the specimen and it can be done profitably only if several specimens are available. As I could not be sure that the smaller specimen here is identical with the larger one, I thought it useless to section the smaller one. Both, therefore, have been preserved intact.

\section{Literature cited}

References prior to 1884 will be found in Lang (1884)

Bock, Srxten

1913. Studien über Polycladen. Zool. Bidr., vol. 2, pp. 31-343, 67 figs., 8 pls.

Girard, Charles Frederic

1893. Recherches sur les planariés et les némertiens de l'Amérique du Nord. Ann. Sci. Nat., ser. 7, vol. 15, pp. 145-310, 4 pls.

Hyman, Libbie Henrietta

1940. The polyclad flatworms of the Atlantic coast of the United States and Canada. Proc. U. S. Nat. Mus., vol. 89, pp. 449-495, 8 figs.

1953. The polyclad flatworms of the Pacific coast of North America. Bull. Amer. Mus. Nat. Hist., vol. 100, pp. 265-392, 161 figs.

1954. Some polyclad flatworms from the Hawaiian Islands. Pacific Sci., vol. 8, pp. 331-336, 3 figs.

JACUBOWA, L.

1906. Polycladen von Neu-Britannien und Neu-Caledonien. Jenaische Zeitschr. Med. Naturw., vol. 41, pp. 113-158, 5 pls.

Kato, Kojiro

1934. Polyclad turbellarians from the neighborhood of the Mitsui Institute of Marine Biology. Japanese Journ. Zool., vol. 6, pp. 123-138.

LAIDLAW, Frank

1902. The marine Turbellaria, with an account of some of the species. In Gardiner, The fauna and geography of the Maldive and Laccadive archipelagoes, vol. 1 , pt. 3 , pp. $282-312,2$ pls.

1903a. Notes on some marine Turbellaria from Torres Straits and the Pacific, with a description of new species. Mem. Proc. Manchester Lit. Philos. Soc., vol. 47, No. 5, 12 pp.

1903b. On the marine fauna of Zanzibar and British East Africa, from collections made by Cyril Crossland in the years 1901 and 1902. Turbellaria Polycladida, pt. 1, The Acotylea. Proc. Zool. Soc. London (1903), pp. 99-114, 5 figs., 1 pl.

1903c. Suggestions for a revision of the classification of the polyclad Turbellaria. Mem. Proc. Manchester Lit. Philos. Soc., vol. 48, pt. 1, No. 4, 16 pp.

1904. Report on the polyclad Turbellaria collected by Professor Herdman at Ceylon in 1902. In Report Ceylon Pearl Fisheries of the Gulf of Manaar, pt. 2, Suppl. Rep. No. 9, pp. 127-137, 1 pl. 
Lang, Arnold

1884. Die Polycladen (Seeplanarien) des Golfes von Neapel und der angrenzenden Meeresabschnitte. Naples Zool. Station, Fauna und Flora des Golfes von Neapel . . ., Monogr. XI, 688 pp., 54 figs., $39 \mathrm{pls}$.

Meixner, Adolf

1907. Polycladen von der Somaliküste, nebst einer Revision der Stylochinen. Zeitschr. Wiss. Zool., vol. 88, pp. 385-498, 2 figs., 5 pls.

Plehn, Marianne

1896. Polycladen von Ambon. In Semon, Zoologische Forschungensreisen in Australien und dem Malayischen Archipel, vol. 5, pt. 1, pp. $327-334,1 \mathrm{pl}$.

Prudhoe, S.

1945. On the species of the polyclad genus Paraplanocera. Ann. Mag. Nat. Hist., ser. 11, vol. 12, pp. 195-202, 2 figs.

Stummer-Traunfels, Ritter von

1933. Polycladida. In Bronn, Die Klassen und Ordnungen des TierReichs ..., vol. 4, Abt. 1c, Lief. 179, pp. 3485-3596, 176 figs.,

Willey, A. $1 \mathrm{pl}$.

1897. Letters from New Guinea on Nautilus and some other organisms. Quart. Journ. Micr. Sci., vol. 39, pp. 145-180. 


\section{$2 \mathrm{BHL}$ Biodiversity Heritage Library}

Hyman, Libbie Henrietta. 1955. "Some Polyclad Flatworms from Polynesia and Micronesia." Proceedings of the United States National Museum 105(3352), 65-82. https://doi.org/10.5479/si.00963801.105-3352.65.

View This Item Online: https://www.biodiversitylibrary.org/item/53512

DOI: https://doi.org/10.5479/si.00963801.105-3352.65

Permalink: https://www.biodiversitylibrary.org/partpdf/52462

\section{Holding Institution}

Smithsonian Libraries

\section{Sponsored by}

Smithsonian

\section{Copyright \& Reuse}

Copyright Status: Public domain. The BHL considers that this work is no longer under copyright protection.

This document was created from content at the Biodiversity Heritage Library, the world's largest open access digital library for biodiversity literature and archives. Visit BHL at https://www.biodiversitylibrary.org. 